\title{
Is the Notwithstanding Clause a Viable Option To Maintain Constitutional Supremacy?
}

\author{
Christian Holloway
}

\section{Introduction}

It has become apparent throughout the history of the Canadian Charter of Rights and Freedoms that section 33, or the Notwithstanding Clause, has been utilized very little in the parliamentary arena, yet has been the subject of an abundance of arguments, both in favour and opposed, in the academic spectrum. This is because section 33, to many theorists, is the mechanism that balances the Supreme Court of Canada and maintains constitutional supremacy in Canada. Through research and evaluation, it becomes evident that section 33 is not a viable option to maintain constitutional supremacy, and that judicial supremacy is already in effect. While there are many scholars who see the Supreme Court of Canada as the guardians of the Charter, and judicial supremacy as beneficial, it is a view that places too much faith in the hands of the unelected magistracy. Firstly, this paper will discuss the problems that face the Notwithstanding Clause. This section will demonstrate the problems that developed at its inception with the wording of the section, and how these problems have developed into the issues it faces today with regards to the ramifications that legislatures face if used. The following section will then evaluate the use of the Notwithstanding Clause in relation to the Quebec Charter of the French Language (which may also be referred to as Bill 101), as well as Saskatchewan's Dispute Settlement Act, and the circumstances surrounding both cases. Through examining the Dispute Settlement Act and Bill 101, it demonstrates that the negative implications normally associated with section 33 are not an issue of the Notwithstanding Clause itself, but are a result of external forces. This will provide the ground work for the final argument that the 
Notwithstanding Clause is not doomed, but may find salvation in drastic measures. This final section will discuss methods on how to fix the Notwithstanding Clause in a manner that provides a viable and tangible application in society and is not solely a theoretical solution. This paper will conclude by summarizing the problems, the exceptions, and perhaps the saving of section 33.

\section{What went wrong?}

Section 33 of the Canadian Charter of Rights and Freedoms gives the ability to the legislature to declare an act notwithstanding a provision of the Charter included in section 2 (fundamental freedoms), sections 7-14 (legal rights), and section 15 (equality rights) for a renewable period of five years. ${ }^{1}$ In other words, Section 33 gives the provincial and federal legislatures the ability to override a Supreme Court of Canada interpretation of legislation as contravening to our fundamental freedoms, and/or our legal and equality rights. While the inclusion of this tool was one of the main reasons the Charter was passed with consent from the provinces, it has faced a curse since its inclusion in the Charter. This is due to a number of reasons. Firstly, the way the clause was worded when it was entrenched into the charter led to tensions between the citizens and the government. The Trudeau government worded Section 33 in a way that whoever enacted it was seen as intentionally infringing the rights granted to Canadian citizens. The wording of the Notwithstanding Clause made it a clause to limit the rights of Canadians and is not in line with what the original framers (authors) of the Charter had intentioned. The original intention for the Notwithstanding Clause was in fact derived from "a belief of the Premiers in the inherent superiority of political judgment over judicial judgment in

\footnotetext{
${ }^{1}$ Canadian Charter of Rights and Freedoms. Part 1 of the Constitution Act, 1982, Schedule B to the Canada Act, 1982. U.K. 1982, c. 11.
} 
accommodating competing interests, including interests that bear on the characterization of rights claims". ${ }^{2}$ It was also intended that the Notwithstanding Clause would only be used as a final method to correct the judiciary. ${ }^{3}$ This means that the original framers' intent was not to have section 33 used as a method to constrain the rights of Canadian citizens, but it was a method to maintain supremacy in the hands of legislatures who possessed a stronger grasp on social issues. However, this is not the view taken by the citizens of Canada. The way in which the Notwithstanding Clause is written undermines its intention, and causes it to be seen as an antidemocratic mechanism. This is due to the way it is worded because it was written as a way to 'suspend' a right, and not as something beneficial to social policy or correcting a false judicial decision. ${ }^{4}$ Section 33 is faced with the problem now, that instead of its true intention being brought to light as a method to counter judicial supremacy, it has been permanently tarnished within the public consensus as a way for Parliament to suspend our rights. This has caused many legislatures to fear the political ramifications associated with Section 33, and has resulted in the Notwithstanding Clause seeing very little use in the history of Canadian politics. ${ }^{5}$ These political ramifications, that could face a legislature when enacting the Notwithstanding Clause, stem from the fact that legislatures are accountable to the people. If the public majority has the opinion that Section 33 is against their benefit and suspends their rights, a politician may be faced with future unemployment because of a loss in public support (and therefore the public vote) if it is used.

\footnotetext{
${ }^{2}$ John Whyte. Sometimes Constitutions are Made in the Streets: the Future of the Charter's Notwithstanding Clause (2007), 82.

${ }^{3}$ Christopher P. Manfredi. Judicial Power and the Charter: Canada and the Paradox of Liberal Constitutionalism. (Toronto 2000), 184.

${ }^{4}$ John Whyte. Sometimes Constitutions are Made in the Streets (2007), 84.

${ }^{5}$ Mark Tushnet. Judicial Activism or Restraint in a Section 33 World (2003), 96.
} 
Critics would argue, however, that judicial supremacy has not occurred because the decisions made by the Supreme Court of Canada to deem a piece of legislation unconstitutional are the result of legislative action before it is even brought before the courts. This argument comes from the cabinet centered approach, and is of the belief that the cabinet is the reason the courts have this supremacy when it fails to ensure its legislation is consistent with the Charter and is constitutional. ${ }^{6}$ Giving power to the judiciary in this perspective is a willingness of the legislature. While this belief is accurate in saying that the Cabinet does have the first move, it is incorrect in saying that the cabinet does not ensure its rights are consistent with the Charter. What the Cabinet is not being consistent with is the judiciary's interpretation of the Charter, resulting in judiciary interpretations as the guidelines for legislation. ${ }^{7}$ The proper approach should be that "if the legislature is responsible and respectful of rights, the court should allow it to pursue its agenda, even when this judgment is different from the courts'."8 However, when it comes to the interpretation by the Supreme Court of the rights in question, the legislature will never override a piece of legislation that contravenes the decision by utilizing the Notwithstanding Clause because of the issues that are associated with it. This problem stems back to section 33 in that it is the reason as to why the true intentions of the legislatures are being questioned; regardless of whether their actions are justified or not.

\section{The Notwithstanding Clause in Action}

As previously stated, section 33 of the Charter has rarely been invoked in Canada, only actually being used twice in its history. While the reasons behind the scarcity of its use were

\footnotetext{
${ }^{6}$ James B. Kelly, and Michael Murphy. Shaping the Constitutional Dialogue on Federalism: Canada's Supreme Court as Meta-Political Actor." (2005), 222.

${ }^{7}$ Mark Tushnet. Policy Distortion and Democratic Debilitation: Comparative Illumination of the Countermajoritarian Difficulty (1995), 245.

${ }^{8}$ Tsvi Kahana. Constitutional Cosiness and Legislative Activism. (Toronto 2005), 153.
} 
discussed in the previous section, there have been a handful of attempted and abandoned uses of the Notwithstanding Clause, but only two clear, straightforward examples of actual invocation and the resulting effects of using section 33. The first is the case of $R$. v. Ford and its relation to Bill 101. The second is the use by the government of Saskatchewan in the Dispute Settlements Act. The case of R. v. Ford deals with Quebec's Bill 101 (also known as the Charter of the French Language) and the sections relating to posting signs for businesses within Quebec. Ford brought the case before the Supreme Court of Canada asking them to decide if sections 58 (public signs, posters, and commercial advertising must be in French) and 69 (only the French version of a firm name may be used in Quebec) of the Charter of the French Language infringes the right to freedom of expression guaranteed in section 2(b) of the Canadian Charter of Rights and Freedoms, and similarly section 3 of the Quebec Charter of Human Rights and Freedoms, as well as the right not to be discriminated against based on language in section 10 of the Quebec Charter of Human Rights and Freedoms. The Supreme Court of Canada ruled in favor of Ford and deemed that section 58 and 69 infringed her rights. The immediate response to this decision by the National Assembly of Quebec was to invoke the invalidated sections notwithstanding the provisions in both the Canadian Charter of Rights and Freedoms, and the Quebec Charter of Human Rights (by invoking section 33) rendering it still in effect. While this was a victory for the Notwithstanding Clause it was short lived. After the five year renewable period of the Notwithstanding Clause, the Quebec government chose not to renew it. This, however, does not mean it was not successful in its use of the Notwithstanding Clause. Although Quebec chose not to re-invoke the Notwithstanding Clause, and instead amended its Charter of the French Language, this does not mean it could not have. ${ }^{9}$ This demonstrates that the Notwithstanding

\footnotetext{
${ }^{9}$ James B. Kelly and Michael Murphy. Shaping the Constitutional Dialogue on Federalism, (2005), 236.
} 
Clause was a viable option for the government of Quebec to protect the French language. The Quebec government's ability to use the Notwithstanding Clause is an example of the framers' intent behind section 33, and as such, allowed the government and people of Quebec to override a judicial nullification of something important to their policy as a distinct society.

The second case is the Saskatchewan's Government Employee Union Dispute Settlement Act. In this circumstance the Saskatchewan government implemented section 33 because they believed the SGEU Dispute Settlement Act infringed the workers right to the freedom of association as guaranteed under section 2(d) of the Canadian Charter of Rights and Freedoms by using the legislation to end a strike and return to work. Unlike the use of the Notwithstanding Clause in the example of the Quebec Charter of the French Language, the use in the SGEU Dispute Settlement Act is a moment that has stigmatized the Notwithstanding Clause. This is because the use of section 33 in this manner was a pre-emptive measure used by the government of Saskatchewan in fear of it being deemed unconstitutional and of no force and effect by the Supreme Court of Canada. ${ }^{10}$ This action by the Saskatchewan government diverges from the original framers' intent of using the Notwithstanding Clause as a last resort method to implement public policy that limits rights, but is beneficial in its circumstances. Instead Saskatchewan used the notwithstanding clause as a preemptive method to avoid the checks and balances by the Supreme Court of Canada, and to pass legislation that the government of Saskatchewan was aware was unconstitutional. It is this deviation from the original purpose of section 33 , and the framers' original intent, that causes the public to have the negative view of the Notwithstanding Clause it possesses. It is also why legislatures are faced with opposition if they were to try and

\footnotetext{
${ }^{10}$ Christopher P. Manfredi. Judicial Power and the Charter (Toronto 2000), 184.
} 
invoke it today. This does not mean however, that the Notwithstanding Clause is forever condemned from use, but it does however need to be adjusted to have the connotations of being justifiable.

\section{How to salvage section 33}

While it may be seen that the Notwithstanding Clause is a feeble, unused mechanism that possesses a bleak future, there may in fact be hope for it. My argument is that the Notwithstanding Clause has died but the idea behind the framers' intent of section 33 is still very much an important aspect of our constitution. The issue that lies within this dilemma is a question of how to restore the Notwithstanding Clause to a tool that faces no ramifications or scrutiny when it is used. One possible method of salvation for section 33 of the Canadian Charter is the theory of mutual recognition/partnership presented by Tsvi Kahana. The idea of partnership means that the courts and the legislatures act in a respectful manner discussing their individual interpretations of the constitutionality of a piece of legislation to arrive in a medium agreement; the Notwithstanding Clause would therefore only be invoked if it were the intention to achieve constitutionality of legislation. ${ }^{11}$ While the partnership theory does solve the problem of legitimizing the Notwithstanding Clause into an approach in line with the constitution, it arises a few problems. One problem is the principle of mutual recognition/partnership. If the courts and legislatures were to discuss their individual interpretations of the sections in question, and attempt to find a mutual ground where both parties can agree whether a piece of legislation is consistent with the Charter, it would result in the inability of anything to pass and no new legislation would form. This is because the judiciary and legislative actors would each present

\footnotetext{
11 Tsvi Kahana. Understanding the Notwithstanding Mechanism. (Toronto 2002), 263.
} 
their own interpretations, justifications, and reasons behind their views which would create a back and forth repetition between the two. The resulting effect would be a stalemate of mutual recognition that both parties have valid claims to their argument, and no interpretation would ever be agreed upon.

Another approach of how to fix the Notwithstanding Clause is that of a parliamentary Bill of Rights model, similar to one presented by Janet Hiebert. The parliamentary Bill of Rights model is stemmed from the idea that the protection of rights should occur within the government and not, however, solely reliant on the judiciary to determine the constitutionality of legislation. ${ }^{12}$ This approach would eliminate the need for the Notwithstanding Clause because the structure of this argument is to have final authority within the government, the very purpose of the Notwithstanding Clause. This is similar to the cabinet centered approach discussed before in that the discretion of the constitutionality of rights rests within the legislature. It therefore suffers the same criticisms as well. The criticism being that since it is the Supreme Court that gives the second decision on the constitutionality of a piece of legislation, the legislatures are not going to attempt to be constitutionally consistent with the Canadian Charter itself, but will adjust the legislation to be in accordance with the interpretations that will be made by the Supreme Court of Canada; the resulting effect being policy distortion. ${ }^{13}$ The counter to the parliamentary Bill of Rights model that has developed says that "judicial review, rather than restrict democratic principles, protects the very conditions that are necessary for citizens to function equitably". ${ }^{14}$ This perspective of the judiciary has already carried over into Parliament

\footnotetext{
12 Janet L. Hiebert. Parliamentary Bills of Rights: An Alternative Model? (2006), 12.

${ }^{13}$ Mark Tushnet. Policy Distortion and Democratic Debilitation (1995), 245.

${ }^{14}$ Janet L. Hiebert. Charter Conflicts: What Is Parliament's Role? (Montreal 2002), 21.
} 
and has created an environment where the legislatures put forth a piece of legislation without establishing its constitutionality before the fact, and leaves this power to the courts to inspect its legislation. $^{15}$

While the approach of leaving validation to the Supreme Court, and the parliamentary Bill of Rights approach present two different positions, they both face a flaw that makes them unfit for Canadian society. The first position is that of eliminating the judiciary entirely, and having a Parliamentary Bill of Rights method, leaving complete interpretation powers to the legislatures. As we have seen from the SGEU Dispute Settlements Act this method would pose a risk because not all of the legislatures intentions are in the best interest of society, and therefore there requires to be a check and balance on the legislatures interpretation of the constitutionality of a piece of legislation. The second position is that of which is in effect presently in Canada, which is having supreme and final interpretation authority on whether legislation is consistent with the constitution in the domain of the Supreme Court of Canada. This method creates the problem of allowing unelected and unchecked actors to represent a democratic system. It also conflicts with the framers' intent that political judgment is superior to that of judicial judgment. The true issue with both these approaches is the absent Notwithstanding Clause. Section 33 is the tool that allows for a check on the legislatures to occur through the judiciary, but also allowing for a check to take place regarding the judiciary after the fact. Therefore with the exclusion of a Notwithstanding Clause, there is too much power in either one branch.

\footnotetext{
15 Janet L. Hiebert. Parliamentary Bills of Rights, 12.
} 
There does exist one argument however that does present an extremely valid option for the future of the Notwithstanding Clause. This argument is presented by Christopher Manfredi. It is an argument that "just as constitutional amendments require extraordinary majorities to become law, legislative overrides of constitutional decisions should also require an extraordinary majority before becoming effective". ${ }^{16}$ This view presents that, similar to the three-fifths vote to invoke a constitutional amendment, if a legislature would like to invoke a section 33 override to a piece of legislation, it would require more support from democratically elected actors; this would make it more likely to be consistent with correcting the judiciary instead of attempting to achieve political agendas. This argument would be achieved through amending the constitution to adjust the Notwithstanding Clause to encompass a new voting percentage required for use, but also an emphasis on that its use is to only be implemented for correcting the decisions of the Supreme Court of Canada. ${ }^{17}$ While Manfredi's proposition is the best suited for the future survivability of the Notwithstanding Clause, there are some issues that are not addressed. While I believe his argument for a three-fifths vote should be enacted, his view of an emphasis on the way the Notwithstanding Clause should be invoked does not resolve the issue of pre-emptive uses of section 33 like what was witnessed with the SGEU Dispute Settlements Act. To fully resolve this problem, while amending section 33, the new Notwithstanding Clause should possess new codified guidelines specifically outlining that it may only be invoked after the constitutionality of legislation is reviewed by the judiciary. However, the simple amendment of the Notwithstanding Clause to these guidelines would also not resolve the problem of public opinion on section 33. This is why not only the Notwithstanding Clause's methods should be amended but the wording itself in how it is implemented into the Canadian Charter of Rights

\footnotetext{
${ }^{16}$ Christopher P. Manfredi. Judicial Power and the Charter (Toronto 2000), 192.

17 Ibid.
} 
and Freedoms. ${ }^{18}$ This change would allow for Parliament to demonstrate to the public the true intention of the Notwithstanding Clause without being associated with the negatives attached to section 33 at the present time. While it essentially would have the same purpose and effect as the Notwithstanding Clause, by changing the wording in the section of the Charter it would allow for marketing the new section in a positive manner to the public, erasing the political ramifications feared when it is invoked in today's political arena.

\section{Conclusion}

The Notwithstanding Clause certainly has not been the most used section of the Canadian Charter of Rights and Freedoms, nor will this change in the near future. This develops a problem for the system of government in Canada because it has resulted in a shift into an era of judicial supremacy. The reason behind this shift is because the Notwithstanding Clause was intended as the bar protecting against judicial supremacy, and that since this method is no longer a viable option for such purposes, the Supreme Court of Canada has become supreme over the legislatures. This lack of activity has been the curse of section 33 since its inception. The way it has been worded in the Canadian Charter gives the impression that the Notwithstanding Clause's function is to allow legislatures to infringe the rights of Canadian citizens. The wording and the public impression of section 33 is contradictory to the intention of the framers' of the Charter when they included it. The original farmers' intent for the Notwithstanding Clause was to provide a check and balance against the judiciary. However, the history of the use of the Notwithstanding Clause has created even more of a rift in its true purpose. On one hand the invocation of section 33 in the case of the Quebec Charter of the French Language demonstrated

\footnotetext{
${ }^{18}$ Allan E. Blakeney. The Notwithstanding Clause, the Charter, and Canada's Patriated Constitution: What I Thought We Were Doing (2010), 1-9.
} 
a justifiable use of the Notwithstanding Clause to protect a piece of legislation, after it was deemed unconstitutional by the Supreme Court of Canada. On the other hand is the use by the Saskatchewan government preemptively in the SGEU Dispute Settlements Act. This second usage is one of the reasons why the Notwithstanding Clause has the reputation it does for undermining democracy. These reasons are why section 33 needs to be fixed. While many scholars have attempted to solve this issue, as presented above in the arguments by Kahana and Hiebert, the only viable option rests in an adjusted form of Manfredi's argument. This adjusted argument would have the constitution be amended to change the wording of the Notwithstanding Clause to offset the public view of it, and have it revised into a clause that can only be applied reactively and is subject to a vote of three-fifths instead of a simple majority. This demonstrates that section 33 is an example of something that is not broken but needs to be fixed. 


\section{BIBLIOGRAPHY}

Blakeney, Allan E. "The Notwithstanding Clause, the Charter, and Canada's Patriated Constitution: What I Thought We Were Doing." Constitutional Forum 19, no. 1 (2010), $1-9$.

Canadian Charter of Rights and Freedoms. Part 1 of the Constitution Act, 1982, Schedule B to the Canada Act, 1982. U.K. 1982, c. 11

Ford v. Quebec (Attorney-General), [1988] 2 S.C.R. 712.

Hiebert, Janet L. Charter Conflicts: What Is Parliament's Role? (Montreal: McGill-Queen's University Press, 2002).

Hiebert, Janet L. "Parliamentary Bills of Rights: An Alternative Model?" Modern Law Review 69, no. 1: (2006), 7-28.

Kahana, Tsvi. "Understanding the Notwithstanding Mechanism." University Of Toronto Law Journal 52, no. 2: (2002), 221-274.

Kahana, Tsvi. "Constitutional Cosiness and Legislative Activism." University Of Toronto Law Journal 55, no. 1: (2005), 129-154.

Kelly, James B., and Michael Murphy. "Shaping the Constitutional Dialogue on Federalism: Canada's Supreme Court as Meta-Political Actor." Publius: The Journal of Federalism 35, no. 2: (2005), 217-243.

Manfredi, Christopher P. Judicial Power and the Charter : Canada and the Paradox of Liberal Constitutionalism. (Toronto: Oxford University Press 2000).

Quebec Charter of Human Rights and Freedoms, R.S.Q., c. C-12;

Quebec Charter of the French Language, R.S.Q., c. C-11

Saskatchewan's Government Employee Union (SGEU) Dispute Settlement Act, S.S. 1984-85-86, c. 111, s. 9.

Tushnet, Mark. "Policy Distortion and Democratic Debilitation: Comparative Illumination of the Counter-majoritarian Difficulty. Michigan Law Review 94, no. 2: (1995), 245-301

Tushnet, Mark. "Judicial Activism Or Restraint In a Section 33 World." University Of Toronto Law Journal 53, no. 1: (2003), 89-100.

Whyte, John. "Sometimes Constitutions are Made in the Streets: the Future of the Charter's Notwithstanding Clause." Constitutional Forum constitutionnel 16, no. 2: (2007), 79-87. 